\title{
Article
}

\section{Ways of Seeing, Ways of Telling: From Art History to Sport History}

\author{
Hughson, John Ewing \\ Available at http://clok.uclan.ac.uk/13575/
}

Hughson, John Ewing ORCID: 0000-0002-7030-4806 (2015) Ways of Seeing, Ways of Telling: From Art History to Sport History. The International Journal of the History of Sport, 32 (15). pp. 1799-1803. ISSN 0952-3367

It is advisable to refer to the publisher's version if you intend to cite from the work. http://dx.doi.org/10.1080/09523367.2015.1108308

For more information about UCLan's research in this area go to http://www.uclan.ac.uk/researchgroups/ and search for < name of research Group>.

For information about Research generally at UCLan please go to http://www.uclan.ac.uk/research/

All outputs in CLoK are protected by Intellectual Property Rights law, including Copyright law. Copyright, IPR and Moral Rights for the works on this site are retained by the individual authors and/or other copyright owners. Terms and conditions for use of this material are defined in the policies page.

\section{CLoK}

Central Lancashire online Knowledge www.clok.uclan.ac.uk

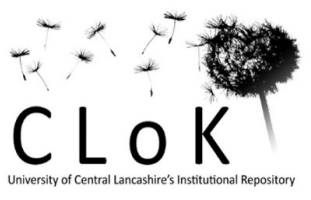




\title{
Ways of Seeing, Ways of Telling: From Art History to Sport History
}

\author{
John Hughson
}

University of Central Lancashire, Preston, England

\begin{abstract}
Art and sport tend to be regarded as very dissimilar areas of human endeavour. Yet the excellence of human achievement attained in both fields promotes a similarity of consideration that suggests a degree of commonality in the respective methodologies of scholars working on the history of art and the history of sport. A particular sensitivity for sport historians has involved wanting to appear to be doing more than telling stories about great sportspeople and sporting contests. While this is an understandable concern, sport historians risk engaging in something other than 'sport history' if they allow anxiety to compromise the discussion of their core subject matter. The history of the history of art reveals a related tension over the existence of a canon of great artists. This tension has not been, and need not be, resolved. Sport historians do well to consider its negotiation as they think through ways to enhance their own modi operandi.
\end{abstract}

Keywords: Renaissance artists; connoisseurship; aesthetics; 'great artist'; appreciation

When Pliny the Elder set out what has come to be regarded as western civilisation's first 'art history', his discussion of the representation of athleticism in Greek statuary was so sympathetic to human movement in competitive toil that a natural relationship between those areas we now know as art and sport seemed permanently assured. 1 But such an understanding was lost over the long historical haul from classical antiquity to modern times. Baron de Coubertin sought to rekindle the 'marriage' between sport and art in the modern Olympic Games via the incorporation of arts competitions. His power of persuasion eventually prevailed, but the reluctance towards this initiative shown by others, involved in the early years of what developed into the Olympic movement, indicated, at the end of the 1800s, just how much the subsequent philosophical acceptance of a mind/body dichotomy in the West had consigned expressions of human excellence into disparate cultural domains. 2

Academic art history and the institutionalising of modern sport were both in formative stages at around the same time in Britain. Some six years after the codification of rules for association football (soccer), which occurred in October 1863, the Slade Professorships in Fine Art at Cambridge and Oxford universities were established concurrently in 1869. The 
first international football match, between Scotland and England, was played in 1872 and the Wimbledon tennis championship commenced in 1877. England played away in the first official international test cricket match against Australia in that same year. During the 1870s John Ruskin, the famous Victorian art patron and polymath, was the first Slade Professor at Oxford. Always the controversialist, Ruskin caused considerable upset when he referred to Michelangelo’s work as 'ostentatious' and 'comparatively weak' when considered against that of earlier Renaissance artists. 3

A good number of Ruskin's audience would have been familiar with Michelangelo’s painting and sculpture via the first-hand experience of grand tourism to Rome and Florence during their educative years. Others would have shared the celebration of 'Il Divino' as communicated by Giorgio Vasari in his Lives of the Artists (first edition 1550; second edition 1568). 4 Available in English since 1685, Vasari's Lives provided the standard for other texts on art history to follow. This included Ruskin’s Modern Painters (1843-60), which, although critical of some 'Old Masters', continued with the canon of 'great artists' approach to account for painters who were active in the first half of the nineteenth century. 5 The first volume of Modern Painters offered an adoration of J. M. W. Turner and a critical defence of his paintings, particularly in regard to his unconventional, yet, according to Ruskin, accurate depiction of nature. The second volume lauded the English Pre-Raphaelites of the mid-1800s and in doing so took Ruskin on an historical excursion back to the Early Renaissance and into praising influential artists from that period, including Botticelli. The periodization of art history and the resultant allocation of artists into timeframes, marked by certain styles, types of artistic representation, choice of subject matter and use of materials, was another technique taken from Vasari. The attribution of 'genius' to certain artists working within the designated historical periods involves a connoisseurship, assumed by Vasari, and the likes of Ruskin after him, based in a confidence that their expert knowledge afforded a privileged position from which correct judgement about the aesthetic worthiness of artworks could be made.

Heading into the twentieth century the line between art history and connoisseurship, although discernible, remained thin. The overlap was flaunted by leading art historian Bernard Berenson, who, writing in the 1920s, actually referred to art connoisseurship as a 'sport' he loved: 'Only one must enjoy it for no utilitarian or pretentious reason, but for its own sake and because it exercises eyes, mind and judgement'. 6 C. L. R. James referred to Berenson in Beyond a Boundary when making his case for cricket to be considered not only in relation to art, but as art. According to James, Berenson's advocacy of 'significant form' in Renaissance 
art hinged on the recognition of two qualities, 'tactile values' and a sense of 'movement'. 7 James quotes Berenson at length comparing painters and wrestlers. Painters, in some cases, have the ability to provide us with a visual representation of physical movement and engagement of the kind we witness in a wrestling match. James contends that cricket surpasses wrestling in aesthetic possibility and that the spectators are drawn to watch because of cricket's 'purely artistic appeal'. 8 The English apostle of the 'aesthetic movement', Walter Pater, made a related observation in the late 1800s when he claimed that the bodily disposition observable in Myron's famous statue Discobulus could be recognised in 'any passable representation of the English cricketer'. 9

However, James's point goes further than the artwork. He dared to actually liken great cricket players to great artists. James was too sophisticated to make simplistic comparisons in this regard, but his claim for 'style', as possessed by some cricket players, suggests a rareness in ability of the kind attributed to 'old master' painters. James effectively positions himself as a connoisseur of cricket in Beyond a Boundary, much of the book given to the discussion of great players and their distinctive aesthetics qualities. Famously, though, James - borrowing from Kipling - contended, 'what do they know of cricket who only cricket know'. 10 The appreciation of great players, for James, cannot be disconnected from the embodied history of social relations, particularly those of nationhood, evident within the 'style' attributed to cricketers by connoisseurial assessment. Accordingly, when referring to Rohan Kanhai he claimed, 'in Kanhai's batting what I have found is a unique pointer of the West Indian quest for identity, for ways of expressing our potential bursting at every seem'. 11 Via this recognition James proclaims, 'cricket is an art, a means of national expression'. 12 In a review of Beyond a Boundary, V. S. Naipaul suggested the book to be as important to England as it is to the West Indies because of the particularly colonial relationship imprinted on cricket as a cultural form. 13

The regard of a reciprocal cultural impact of colonialism via cricket is reminiscent of the position set out by the art historian Bernard Smith in his book, European Vision and the South Pacific. 14 Further to the unsurprising claim that Australian art needs to be understood in relation to British art, Smith contends, from the late 1700s, developments in English art were impacted upon by the voyages made to Australia and the South Pacific by Captain James Cook. In particular, the artwork of William Hodges, painter on Cook's second voyage, created such interest to revive debate about Dryden's notion of the 'noble savage' and to heighten concern, via contrast with his depictions of idyllic scenery, about rampant 
industrialisation in England. 15 His artwork, thus, had a bearing on subsequent portrait and landscape painting in England, in a way described by Smith scholar, Peter Beilharz as, 'the reflux from below...return[ing] to haunt the metropolitan consciousness'. 16 When Smith wrote of the 'Antipodes' he was referring not so much to a place but to a relationship between the colonial centre and periphery. Although 'unequal by nature' it is a relationship that involves 'a great deal more fluidity than those formally in control could themselves imagine'. 16 Beilharz uses the term 'cultural traffic' to explain the dynamism of the antipodean relationship in its unsettling of cultural hegemony. 17

This art historical notion of 'cultural traffic' has a particular resonance for sport history given the direct cultural engagement between the colonial centre and peripheries that sport involves. This has pertinence to James's discussion of cricket in the Caribbean and to histories of cricket on the subcontinent, such as Ramachandra Guha's history of cricket in India. 18 An especially interesting example comes from the history of rugby union football. In 1888-89 a select rugby team from New Zealand, comprising a majority of Māori players, in what has become known as the Native Tour, visited Britain for a series of matches. The host nation response to the tour was favourably recorded in the British press; referred to patronizingly as an 'ever-welcome colonial invasion' and the Māori players congratulated on their civilised conduct on and off the field. 19 However, related references praising the adaptation to rugby by the 'colonial race' failed to account for the original contribution to the sport by Māori players in a way indicative of 'cultural traffic'. 20 It was on this tour that the 'wing-forward' formation was seen for the first time in rugby away from New Zealand. This type of play was invented by Thomas Rangiwahai Ellison, as described in his book The Art of Rugby, published in 1902. Ellison remarked, in regard to the 'Britishers', 'their play was of one style ...they all seem to have tumbled into a groove and stuck there'. 21 The 'wing-game' was subsequently adopted very successfully by All Black teams over the next 30 years, until it was counteracted by a codified rule change to introduce an eight-player scrum in 1932. 22

As one of the most eminent historians of sport, Allen Guttmann, points out, there is not a 'perfect correspondence between sports history and art history'. 23 Although 'sports and the arts are both cultural universals' with 'point-to-point connections', they differ in that creating a work of art 'is more explicitly and immediately expressive and interpretative than a sports contest'. 24 For this fundamental reason sport can be represented in artworks in a way that works of art cannot be represented in sport. This also creates a disciplinary imbalance; a sport historian's look to art history for hermeneutical or methodological leads is unlikely to be 
reciprocated. The art historian's interest in sport history is in subject matter rather than in disciplinary common ground. Be this as it may, the sport historian can find succour in art history for the very particularity of that discipline's ongoing struggle to negotiate a means by which to deal with matters of choice, taste and moral judgement. The 'great artist' approach has proved hard to shake even within the work of art historian's mindful of subjective excesses. For example, in The Story of Art, first published in 1950, Ernst Gombrich, deliberately, prioritised investigation into the cultural context of artists' works over an emphasis on heralding their artistic ability. 25 On this basis he defended Tintoretto against the criticism of Vasari. What Vasari regarded as the Venetian artist's crude and careless execution, Gombrich saw as an innovation that moved painting beyond the obsession with technical excellence, which had reached a high point by around the mid-1500s. 26 Nevertheless, Gombrich’s approach, which still assembled artists into an historical lineage, was criticised as connoisseur-like. 27

Even as art history took a feminist turn in the 1970s, one of that perspective's best-known essays, by Linda Nochlin, posed the question, 'Why have there been no great women artists?' 28 Nochlin's answer that the 'institutional' preconditions for achievement have been denied to women, tackled a long-held prejudice within art history and criticism about the inferior capabilities of female artists. Nevertheless, as posed, the question itself retains the premise that great artists have existed and might still exist. Social enquiry fairly intervenes to look into the social conditions of art and its production, but this does not mean that art history can be reduced to an explanation of objective outcomes. As Robert Hughes claimed, art 'deals with nuances that have no objective importance'. Yet the seriousness of art is derived from its subjective nature in that 'the human animal is an animal who judges'. 29 Sport historians are especially sensitive to suggestions that their practice is but connoisseurship, engaged in debates over which sportsperson or which sports team was the best in a certain era or of all time. Of course, it is much more than this, just as art history is more than debates over great painters. But for sport history to be about sport history, it must have the discussion of sport and sportspersons as its core subject matter. When this is not the case the scholarship on offer is something other than sport history. Art history has long been opened to the interrogation of social inquiry, while retaining its concerns of 'categorising, interpreting, describing and thinking about works of art'. 30 Sport historians can learn well from its example. 


\section{Note on the Contributor}

John Hughson is Professor of Sport and Cultural Studies at the University of Central Lancashire. His latest book is England and the 1966 World Cup: A Cultural History (Manchester University Press, 2016).

\section{Notes}

1. Healy, Pliny the Elder.

2. Stanton, The Forgotten Olympic Arts Competitions.

3. Hilton, John Ruskin, 483.

4. Vasari, Lives of the Artists.

5. Ruskin, Modern Painters.

6. The quote is from Berenson's essay 'Nine Pictures in Search of Attribution', cited by Hatt and Klonk, 40.

7. James, Beyond a Boundary, 200-1.

8. Ibid., 201-2.

9. Pater, 'The Age of the Athletic Prizemen', 282.

10. James, Beyond a Boundary, 252.

11. James, Kanhai, 165.

12. Ibid., 171.

13. Naipaul, 'Cricket', 22.

14. Smith, European Vision and the South Pacific.

15. Ibid., 73-83.

16. Beilharz, Imagining the Antipodes, 78.

17. Beilharz, 'Bernard Smith’, 433-4.

18. Guha, Corner of a Foreign Field.

19. Ryan, Forerunners of the All Blacks, 44.

20. Ibid., 50 .

21. Ellison, The Art of Rugby, 66.

22. Hughson, The Making of Sporting Cultures, 79.

23. Guttmann, Sports and American Art, 234.

24. Ibid., 1 and 234.

25. Gombrich, The Story of Art. 
26. Ibid., 286.

27. Arnold, Art History, 34.

28. Nochlin, 'Why Have There Been No Great Women Artists?'

29. Hughes, The Shock of the New, 364.

30. Arnold, Art History, vi.

\section{References}

Arnold, Dana. Art History: A Very Short Introduction. Oxford: Oxford University Press, 2004.

Beilharz, Peter. Imaging the Antipodes: Culture, Theory and the Visual in the Work of Bernard Smith. Cambridge: Cambridge University Press, 1997.

Beilharz, Peter. 'Bernard Smith', in Dictionary of Cultural Theorists, eds Ellis Cashmore and Chris Rojek, 433-4. London: Arnold, 1995.

Ellison, Thomas Rangiwahai. The Art of Rugby: With Hints and Instructions on Every Point of the Game. Wellington: Geddis and Blomfield, 1902.

Gombrich, E.H. The Story of Art, thirteenth edition. London: Phaidon / Book Club Associates, 1978 [1950].

Guha, Ramachandra. Corner of a Foreign Field: The Indian History of a British Game. London: Picador, 2002.

Guttmann, Allen. Sports and American Art: From Benjamin West to Andy Warhol. Amherst and Boston: University of Massachusetts Press, 2011.

Hatt, Michael and Klonk, Charlotte. Art History: A Critical Introduction to its Methods. Manchester: Manchester University Press, 2006.

Healy, John. Pliny the Elder: Natural History: A Selection. London: Penguin Classics, 1991.

Hilton, Tim. John Ruskin. New Haven: Yale University Press, 2002.

Hughes, Robert. The Shock of the New: Art and the Century of Change. London: British Broadcasting Corporation: 1980.

Hughson, John. The Making of Sport Cultures. London: Routledge, 2009.

James, C. L. R. Beyond a Boundary. London: Serpent’s Tail, 2000 [1963].

James, C. L. R. 'Kanhai: A Study in Confidence', in Cricket: C. L. R. James, ed Anna Grimshaw, 116-7. London: Allison and Busby, 1986.

Naipaul, V.S. 'Cricket', in The Overcrowded Barracoon and Other Articles, 17-22. London: Andre Deutsch, 1972.

Nochlin, Linda. 'Why Have There Been No Great Women Artists?' in Women, Art and Power and Other Essays, 145-78. London: Thames and Hudson, 1989. 
Pater, Walter. 'The Age of the Athletic Prizemen: A Chapter in Greek Art' in Greek Studies: A Series of Essays, second edition, 269-99. London: Macmillan, 1910.

Ruskin, John. Modern Painters, edited an abridged by David Barrie. London: Andre Deutsch, 1989.

Ryan, Greg. Forerunners of the All Blacks: The 1888-89 New Zealand Native Football Team in Britain, Australia and New Zealand. Christchurch: Canterbury University Press, 1993.

Smith, Bernard. European Vision and the South Pacific. Oxford: Oxford University Press, 1969.

Vasari, Giorgio. The Lives of the Artists. Oxford: Oxford World Classics, 2008. 
